\title{
Rhabdomyolysis After Sleeve Gastrectomy: Increase in Muscle Enzymes Does not Predict Fatal Outcome
}

Pietro Forestieri • Antonio Formato • Vincenzo Pilone • Antonietta Romano • Angela Monda •

Salvatore Tramontano

Published online: 19 February 2009

(C) Springer Science + Business Media, LLC 2009

Erratum to: OBES SURG

DOI 10.1007/s11695-007-9356-z

In the original version of the article, the authors' first and surnames were transposed. The correct authorship is as follows: Pietro Forestieri, Antonio Formato, Vincenzo Pilone, Antonietta Romano, Angela Monda, and Salvatore Tramontano. Where first initials are used in the footnote, the text should read Forestieri P., Formato A., Pilone V., Romano A., Monda A., and Tramontano S.

The online version of the original article can be found at http://dx.doi. org/10.1007/s11695-007-9356-z.

P. Forestieri $(\bowtie) \cdot$ A. Formato $\cdot$ V. Pilone $\cdot$ A. Romano $\cdot$

A. Monda $\cdot$ S. Tramontano

Department of General, Geriatric and Oncologic Surgery

and Advanced Technology, Università degli Studi Federico II,

Via S. Pansini 5,

1-80132 Naples, Italy

e-mail: forestie@unina.it 